Editorial

\title{
A respeito do peso e da leveza
}

Marco Antonio Guimaräes da Silva marco@atlanticaedu.com.br

Tenho que reconhecer que os meus editoriais, amparados em críticas do tecido social e da "subclasse política", tem-se pautado pela pesada caracterizaçáo que dou aos antagonistas que crio, verdadeiros Górgonas do século XXI.

A metáfora peso, entendida como a subtração da leveza, pode também ser pensada como a inércia que envolve os homens, aniquilando quaisquer reaçôes, ou quem sabe também interpretada como a opacidade que reflete o lado escuro e sombrio da natureza humana, todas aplicadas aos protagonistas de meus editoriais. Estava, pois, decidido a iniciar uma nova fase e inaugurar uma escrita com figuras mais leves, tal e qual fizera Milan Kundera, quando cria o personagem Tomas em a Insustentável Leveza do Ser.

Já havia, em editorial passado, introduzido essa idéia, quando sugeria que nos tornássemos turistas em nossa própria terra, vivendo sem nenhum compromisso com quaisquer problemas, sejam de ordem política ou social. Kundera avança ainda mais, incluindo, dentro dessa total falta de compromisso, as relações amorosas.

Reconheço o perigo da omissão e da linearidade do agir, opçóes do protagonista da obra tcheca mencionada já tematizadas no meu citado editorial. No entanto, para evitar falsas interpretaçōes e equívocos, sugiro uma leitura com reflexôes diretamente remetidas a Nietzsche (Eterno Retorno) e indiretamente a Hegel (tese - antítese).

"E se um dia ou uma noite um demônio se esgueirasse em tua mais solitária solidão e te dissesse: Esta vida, assim como tu vives agora e como a viveste, terás de vivê-la ainda uma vez e ainda inúmeras vezes: e não haverá nela nada de novo, cada dor e cada prazer e cada pensamento e suspiro e tudo o que há de indivisivelmente pequeno e de grande em tua vida há de te retornar, e tudo na mesma ordem e seqüência - e do mesmo modo esta aranha e este luar entre as árvores, e do mesmo modo este instante e eu próprio. A eterna ampulheta da existência será sempre virada outra vez - e tu com ela, poeirinha da poeira! Não te lançarias ao chão e rangerias os dentes e amaldiçoarias o demônio que te falasses assim? Ou viveste alguma vez um instante descomunal, em que lhe responderias: "Tu és um deus e nunca ouvi nada mais divino!" Se esse pensamento adquirisse poder sobre ti, assim como tu és, ele te transformaria e talvez te triturasse: a pergunta diante de tudo e de cada coisa: Quero isto ainda uma vez e inúmeras vezes?" pesaria como o mais pesado dos pesos sobre o teu agir! Ou, então, como terias de ficar de bem contigo e mesmo com a vida, para não desejar nada mais do que essa última, eterna confirmação e chancela?"

Friedrich Nietzsche, A Gaia Ciência, aforismo 341.

Talvez fosse essa a grande questáo de nossas vidas. Queremos viver essa vida mais uma, mais duas, mais $\mathrm{n}$ vezes?

De volta à leveza dos meus personagens. Veio a chuva no Rio e com ela a tragédia, vitimando e matando centenas e desamparando milhares de pessoas. Com essa chuva, veio também a inevitável contestação de uma incompetência administrativa ou de descaso com a coisa pública, amparadas, respectivamente, sob a minha ótica, em visóes jurídicas culposas ou dolosas.

Não haveria, portanto, como subtrair o "peso" de meus antagonistas, porque a culpabilidade está presente.

Mas, e nós, representados pelos sofridos cidadãos, estaríamos condenados a ser protagonistas cuja leveza do ser nos colocaria como meros e conformados expectadores? Aí estaria o meu grande e paradoxal desafio: dar leveza aos meus protagonistas e, simultaneamente, levá-los a romper o círculo vicioso e as omissôes por eles cometidas.

Tenho esperanças; afinal Perseu sustentou-se nas nuvens e no vento para vencer a Medusa. 